\title{
Identification and Characterizations of Pathogenic Fungal Species Associated with Symptoms of Cassava Anthracnose in Ivory Coast
}

\author{
Ehui Kouadio Jean Nestor ${ }^{1^{*}}$, Toure Howélé Michaëlle Andrée Célestine ${ }^{1}$ \\ Kouame Koffi Gaston ${ }^{2}$, Abo Kouabenan ${ }^{3}$ and Kone Daouda ${ }^{1}$
}

${ }^{1}$ Training and Research Unit (Faculty) of Biosciences, Laboratory of Plant Physiology, University Félix Houphouët-Boigny of Cocody-Abidjan, 22 B.P. 582 Abidjan 22, Ivory Coast.

${ }^{2}$ Department of Plant Biology, Biological Sciences Training and Research Unit, Péléforo-GbonCoulibaly University (UPGC), B.P. 1328 Korhogo, Ivory Coast.

${ }^{3}$ Training and Research Department in Agriculture and Animal Resources (DFR-ARA), National Polytechnic Institute Felix Houphouet-Boigny s(INP-HB), Laboratory of Plant Pathology and Plant Biology, BP 1313 Yamoussoukro, Ivory Coast.

\begin{abstract}
Authors' contributions
This work was carried out in collaboration between all authors. Author EKJN designed the study, performed the statistical analysis, wrote the protocol, and wrote the first draft of the manuscript. Author KKG has helped to identify fungal isolates and corrected first draft. Author THMAC has helped to collect samples. Author AK read and corrected the first draft. Author KD is the scientific director of project. He corrected the protocol. All authors read and approved the final manuscript.
\end{abstract}

Article Information

DOI: 10.9734/ARRB/2018/v30i430017 Editor(s):

(1) Dr: Jin-Zhi Zhang, Key Laboratory of Horticultural Plant Biology (Ministry of Education), College of Horticulture and Forestry Science, Huazhong Agricultural University, Wuhan 430070, China. (2) Prof. George Perry, Dean and Professor of Biology, University of Texas at San Antonio, USA

Reviewers:

(1) Robinson, K. Victor, Rivers State University, Nigeria. (2) Clint Magill, Texas A\&M University USA. (3) ABA-Toumnou Lucie, Laboratory of Biological and Agronomical Sciences for Development, University of Bangui, Central African Republic. Complete Peer review History: http://www.sdiarticle3.com/review-history/47294

Original Research Article

Received 22 October 2018

Accepted 17 February 2019

Published 01 March 2019

\section{ABSTRACT}

Cassava anthracnose is a plant disease that affects cassava stems, petioles and fruits. The aim of this study was to analyze the diversity of cassava anthracnose symptoms in Ivory Coast and then to identify and characterize the associated fungal genera. Surveys were carried out in all agricultural zones of the country from July to November, in 2014, 2015, 2016 and 2017. Infected samples

*Corresponding author: E-mail: kouadiojeannestore@yahoo.com 
consisting of stems cut with a small number of superficial cankers $(0.3 \%)$, distorted stems $(25.77 \%)$, and necrotic stems and petioles $(65.18 \%)$ were collected. Also, withered and dried apical buds $(8.76 \%)$ were harvested. Fungal pathogens derived from samples were Colletotrichum gloeosporioides (35.08\%), Fusarium sp. (27.19\%) and Botrytis sp. (19.73\%) genera and undetermined strains (17.98\%). Genera were characterized by morphological and microscopic characteristics. Parasitic pressure increased to 80 and $100 \%$ respectively for Botrytis sp. genus and Colletotrichum gloeosporioides and Fusarium sp genera. Fungal genera have caused lesions on stem and petioles in green house with diameters sizes 46,71 and $72 \mathrm{~mm}$ respectively for genera Botrytis sp, Fusarium sp and Colletotrichum gloeosporioides. Aggressiveness index of Botrytis sp. genus was 3 and 4 respectively for Colletotrichum gloeosporioides and Fusarium sp. genera. The mycoflora of cassava aerial organs alteration, linked to the symptoms of anthracnose, is composed of genera of great economic importance and scientific interest.

Keywords: Cassava; anthracnose; mycoflora; Colletotrichum gloeosporioides; Fusarium sp; Botrytis $s p$.

\section{INTRODUCTION}

Cassava is the second most important food crop in Ivory Coast due to its tuber yield. Its production contributes to the reduction of the food deficit through the multiplicity of products derived from its artisanal and industrial processing while supporting economic activity for poverty reduction [1]. However, fresh cassava tuber yields in Ivory Coast decreased from $4,239,303$ tons in 2014 to $3,674,818$ and $3,210,614$ tons respectively in 2015 and 2016 [2]. Cassava anthracnose, which is the most damaging fungal disease of cassava in the tropical zone, has reached worrying levels of incidence and severity in Ivory Coast [3,4]. Notwithstanding abiotic factors, viral and bacterial phytopathological factors, cassava anthracnose disease causes enormous economic losses through alteration of cuttings quality and yield losses related to young plant mortality $[5,6]$. It is a disease of the aerial parts of cassava plants, especially the stem and leaf petioles [7]. Symptoms include cankers, distortions, numerous lesions and severe necrosis on stems, petioles and leaf axils. Petiole wilt followed by severe defoliation leading to drying of the buds with stem exudate has also been described [4]. The establishment of anthracnose is promoted by injuries or tissue weakening that will constitute the entry points for the infectious propagules of Colletotrichum gloeosporioides Penz manihotis [8]. In addition, many other pathogenic fungal species or saprophytes have often been associated with cassava disease. Nyaka [9] have identified in Cameroon, on cassava root diseases, various fungal strains including Colletotrichum sp., Fusarium sp., Pestalotia sp., Geotrichum sp., Sphaerostilberepens, Trichoderma viride and
Botryodiplodia theobromae. Also, in Ivory Coast Silué [10] have identified, on anthracnose symptomatic of Cashew (Anacardium occidentale L.), Colletotrichum gloeosporioides, Pestalotia heterocomis, Lasiodiplodia theobromae and other unidentified fungal strains. The openings that lead to cassava anthracnose could be secondary routes of infestation for polyphytophagous fungal genera. Knowledge concerning mycoflora associated with cassava aerial organs alteration, generally, and that related to the symptoms of cassava anthracnose disease, particularly in Côte d'Ivoire, is not available.

The aim of this study was to analyse the diversity of cassava anthracnose symptoms in Ivory Coast and then to identify and characterize associated pathogenic fungal genera.

\section{MATERIALS AND METHODS}

\subsection{Plant Materials}

Cassava is the main crop observed and evaluated. The various varieties produced in the seven agro-ecological zones (AEZ) of Ivory Coast were examined in their development of anthracnose symptoms. Specifically, some stems and petioles infected and healthy cuttings were harvested from farmer plots for screening.

\subsection{Cassava Anthracnose Disease Symptomatic Assessment and Sampling}

Surveys were conducted in all the agricultural areas of the country from July to November, from 2014 to 2017. An average of three farmer plots, bordering the roads and 10 to $20 \mathrm{~km}$ apart, were 
subjected to health assessment through plant observations [11]. It was essential to identify different cassava anthracnose symptoms. The infected area of the plant, morphology and coloration of necrotic surface have been considered for symptomatic diversity. Samples were taken on the basis of the different symptomatic level of cassava anthracnose disease defined by the IITA rating scale [12]. This scale is defined as follows: $1=$ No symptom; 2 =Shallow cankers on woody stems appearing towards the end of the season; $3=$ Many deep cankers on stems that have become woody and deformed; 4= Many oval lesions on green stems (herbaceous, not woody), lesions on young stems and severe leaf axil necrosis; $5=$ Withering, strong defoliation and death of part of or whole apical buds. Infected stems and petioles were collected for analysis.

\subsection{Isolation, Identification and Characterizations of Fungi Associated with Cassava Anthracnose Disease Symptoms}

Isolations and purifications took place in the laboratory according to the methodology of Fokunang and Dixon [13]. Samples were cleaned with $70 \%$ alcohol and five explants were taken from front of necrosis. They were disinfected in $10 \%$ sodium hypochlorite for 3 minutes. Explants were also washed 3 times for 3 minutes with sterile distilled water. They were dried and seeded on PDA (Potato Dextrose Agar) medium $(20 \%)$. After 72 hours of incubation, fungal colonies emerged were transplanted on new PDA medium until a pure isolate was obtained. The cultural characteristics that contributed to the diversity of the isolates were the appearance and colouring of the aerial thallus. Morphological aspects were based on the general shape of the conidia and mycelium. Genera identifications, based on these characters, were made using the keys of Webster and Weber [14], Barnet and Hunter [15] and Malloch [16]. Morpho-metric assessments focused on radial mycelial growth and conidia size. Mycelial growth evaluation was done daily, based on the measurement, along two orthogonal axes, from a mycelial disc inoculated on a PDA medium (20\%) [17]. The measurement of conidia size focused on measuring length along the longitudinal axis and width along the vertical axis of conidia. A drop of a conidia suspension was mounted between the slide and the cover slip and measurements were made under an optical microscope at $40 \mathrm{X}$ magnification to $20 \mu \mathrm{m}$.

\subsection{Assessment of the Fungal Parasitic Pressure of Cassava Anthracnose Symptoms}

A total of 5 explants were inoculated on PDA medium (20\%), for each sample treated. Four of the explants were taken at the growth front and the last one was taken in the center of the symptom initiation zone. Parasite pressure was assessed by determining population and proportion of fungal contaminants arising from infected samples. The fungal population was assessed through the diversity of emerging strains on all treated samples. The Proportion of Contaminant $(\mathrm{Pc})$ was calculated according to the formula (1) of Spurr and Welty [18]:

$$
\text { Contaminant proportion }(\mathrm{Cp})=\frac{\text { Contaminant Eff }}{5 \times \mathrm{NE}} \times 100
$$

Contaminant $\mathrm{Eff}=$ Total contaminants in the collection; $\mathrm{NE}=$ Total number of samples treated.

\subsection{Characterization of the Pathogenic Potential of Fungal Genera and Koch's Postulate}

This characterizations consisted in evaluating the aggressiveness of three genera on the original host and satisfying Koch's postulate [19]. The local variety, sensitive to anthracnose, Yacé was used for the pathogenicity test. After 6 weeks of culture in green house, a vigorous plant was artificially injured with a cold sterile needle. The injuries were applied to the knotted area, in the axil and on the petioles of the leaves, of each plant. Inoculations were performed by placing a small mycelial disc, taken from a 14-day-old culture medium, on the injuries. Three morphotypes of each genus were used for pathogenicity assessment. The evaluations took place 30 days after inoculations. The diameter of the necrosis was calculated according to the formula (2) used by Kouamé [19]:

Diameter of lesions $(L D)=\frac{\text { Length of lesions }+ \text { Width of lesions }}{2}$

The aggressiveness was assessed using a scoring scale used by Wokocha [20] with a change in intervals. Aggressiveness index (Al) was calculated according to following formula (3):

$$
\text { Aggressivity index }(A I)=\frac{\sum R i}{N}
$$


$R=$ Number of infected points with the same size; $\mathrm{i}=$ level of infection $; \mathrm{N}=$ total number of lesions.

Levels of infection: $1=$ lesion $<1 \mathrm{~mm} ; 2=$ lesion from 1 to $3 \mathrm{~mm} ; 3=$ lesion from 4 to 6 $\mathrm{mm}$;

4 = lesion from 7 to $10 \mathrm{~mm} ; 5=$ lesion $>10$ $\mathrm{mm}$.

\subsection{Statistical Analysis}

Statistical analyses were carried out using Statistica version 7.1 software. Morpho-metric data of isolates and their aggressiveness on the host plant were subjected to the ANOVA analysis of variance (one factor). The significantly different averages were classified according to Duncan's grouping test at $5 \%$ threshold.

\section{RESULTS}

\subsection{Symptomatic Diversity of Cassava Anthracnose Infection Stages and Mycoflora Hosted}

In the infected plots visited, symptoms observed on the collected samples are shown in (Fig. 1). They consisted of a small number of superficial cankers $(0.3 \%)$ located on added stems. Also, deformations $(25.77 \%)$ of stems due to bulges and distortions were collected on stems and petioles. As a result, we collected green stems and petioles injured covered with necrotic lesion $(65.18 \%)$. Finally, dieback and dried apical buds $(8.76 \%)$ were collected. The fungal population hosted consist of genera of Colletotrichum gloeosporioides, Fusarium sp., Botrytis sp. and unidentified strains. Isolates of Colletotrichum gloeosporioides and unidentified strains were isolated from all symptomatic stages while Fusarium sp. genus was hosted only by stages 3,4 and 5 . Botrytis sp. genus were found in stages 3 and 4 mycoflora (Table 1).

\subsection{Phenotypic Diversity of Mycoflora of Cassava Anthracnose Symptoms}

Three fungal genera were distinguished in the mycoflora of cassava anthracnose symptoms, depending on the samples treated. They are shown in Figs. (2-4) under different phenotypes depending on the appearance of the aerial thallus and the shape of the conidia. Colletotrichum gloeosporioides genus presented several morphotypes with cylindrical and fusiform conidia (Fig. 2). Fusarium sp. genus also presented several morphotypes producing fusiform macro-conidia and cylindrical microconidia (Fig. 3). Morphotypes of Botrytis sp. genus had rounded conidia (Fig. 4). Mean radial mycelial growth was higher between 72 and 120 hours. The average lengths of the cylindrical conidia of Colletotrichum gloeosporioides were between 27.37 and 29.82 for average widths between 6.67 and $7.53 \mu \mathrm{m}$. The mean lengths of the fusiform conidia were between 40.97 and $55.40 \mu \mathrm{m}$ for mean widths between 4.45 and $7.13 \mu \mathrm{m}$. The rounded conidia of Botrytis sp. genus had average lengths between 6.63 and $7.40 \mu \mathrm{m}$ and average widths between 6.67 and $7.94 \mu \mathrm{m}$.

\subsection{Parasitic Activity of Mycoflora Morphotypes of Casava Anthracnose Disease Symptoms}

Three genera have induced lesions on the internodes of the stems, on the petioles and in the axil of the leaves. Average diameter of lesions and mean aggressiveness index of genera were revealed with significant difference $(P=0.01)$. Parasitic pressure was very high for all three genera. Colletotrichum gloeosporioides and Fusarium sp. genus were the most abundant fungal population and were found with total parasitic pressure on the seeded explants. Botrytis sp. genus could be revealed by four out

Table 1. Fungal genera associated with cassava anthracnose disease stages

\begin{tabular}{lllll}
\hline $\begin{array}{l}\text { Infection stages of the } \\
\text { samples }\end{array}$ & \multicolumn{4}{c}{ Fungal populations proportion (\%) } \\
\cline { 2 - 5 } & $\begin{array}{l}\text { Botrytis sp. } \\
\text { genus }\end{array}$ & $\begin{array}{l}\text { Colletotrichum } \\
\text { gloeosporioides }\end{array}$ & $\begin{array}{l}\text { Fusarium sp. } \\
\text { genus }\end{array}$ & $\begin{array}{l}\text { Non } \\
\text { identifiées }\end{array}$ \\
\hline Stage 2 & 0 & 1 & 0 & 48 \\
Stage 3 & 65 & 45 & 48 & 27 \\
Stage 4 & 35 & 53 & 51 & 15 \\
Stage 5 & 0 & 1 & 1 & 10 \\
Fungal population (\%) & $19,73 \mathrm{c}$ & 35,08 a & $27,19 \mathrm{~b}$ & $17,98 \mathrm{~d}$ \\
\hline Letters (a, b, $c$ and d) refer to different statistical averages classes of fungal population proportion with significant \\
\multicolumn{5}{r}{ difference according to Duncan's grouping Test at 5\% threshold. }
\end{tabular}


of five explants and was lower than those of the other two genera in fungal population. The average diameters of necrosis caused by morphotypes of Colletotrichum gloeosporioides and Fusarium sp. were larger than those of morphotypes of Botrytis sp. genus. Morphotypes of Colletotrichum gloeosporioides and Fusarium $\mathrm{sp}$. genera were more aggressive on stems and petioles than morphotypes of the genus Botrytis sp. (Table 2).
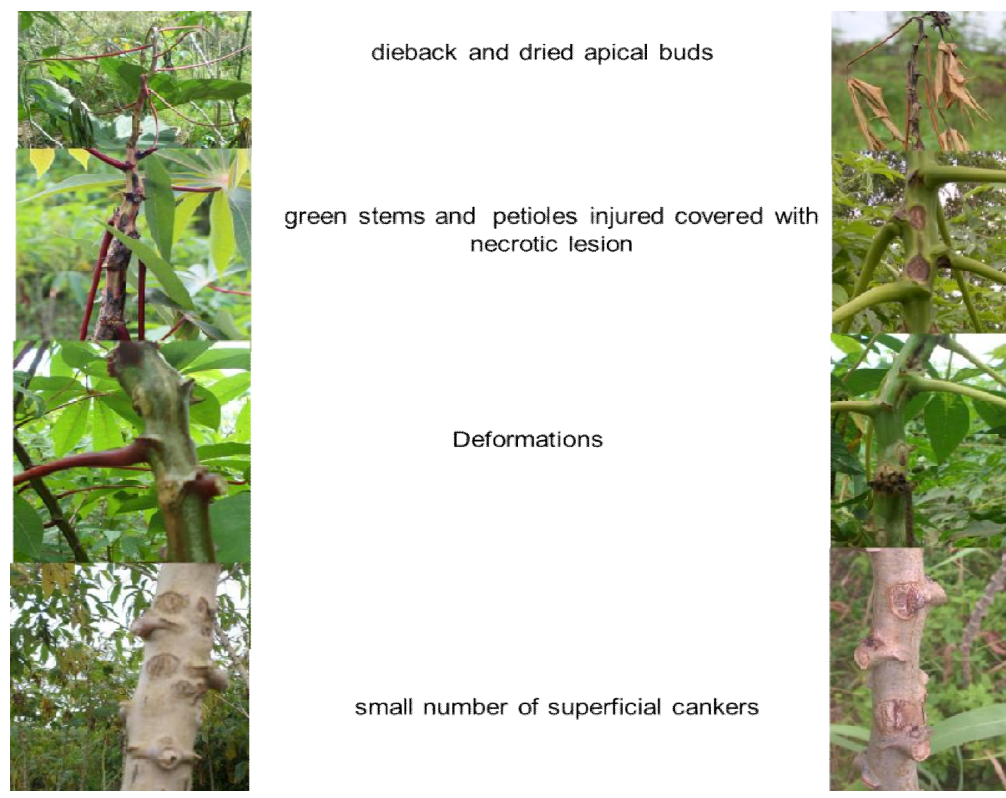

Fig. 1. Symptomatic diversity of cassava anthracnose disease in Ivory Coast

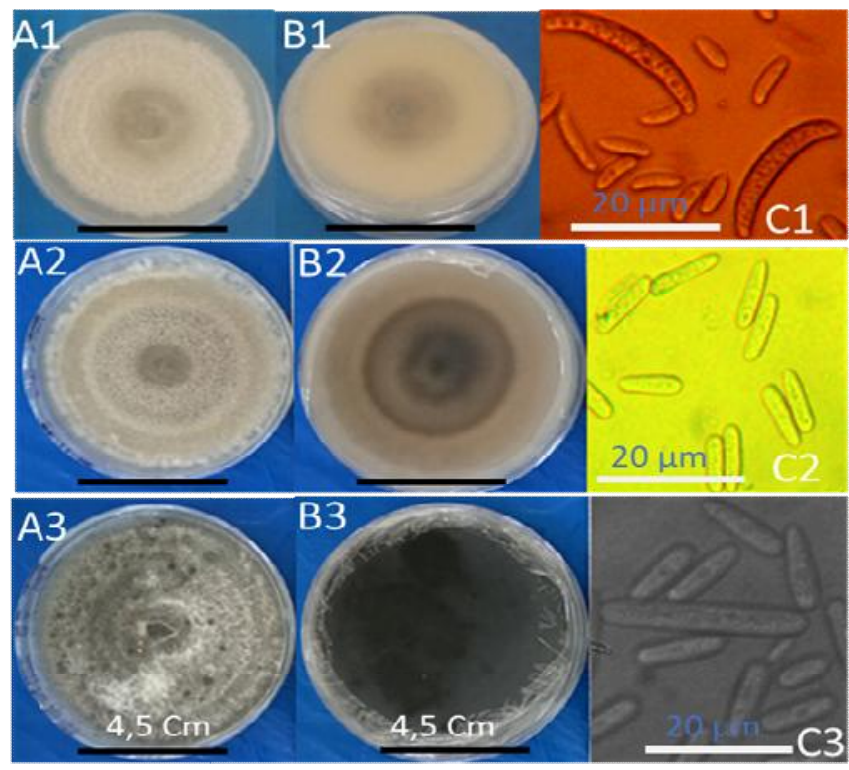

Fig. 2. Morpho-cultural and microscopic characteristics of isolates of the genus Colletotrichum gloeosporioides

(Morphotype AgYSt4: A1 and B1: cottony phenotype with $10.5 \mathrm{~mm} /$ day (growth); C1: conidia size $27.37 \times 7.01$ $\mu m)$

(Morphotype BotPet: $A 2$ and B2: cottony phenotype with $8.42 \mathrm{~mm} /$ day (growth); C2: conidia size $28.9 \times 7.5 \mu \mathrm{m}$ ) (Morphotype PetVB: A3 and B3: cottony phenotype with $15.1 \mathrm{~mm} /$ day (growth); C3: conidia size $29.9 \times 6.9 \mu \mathrm{m}$ ) 

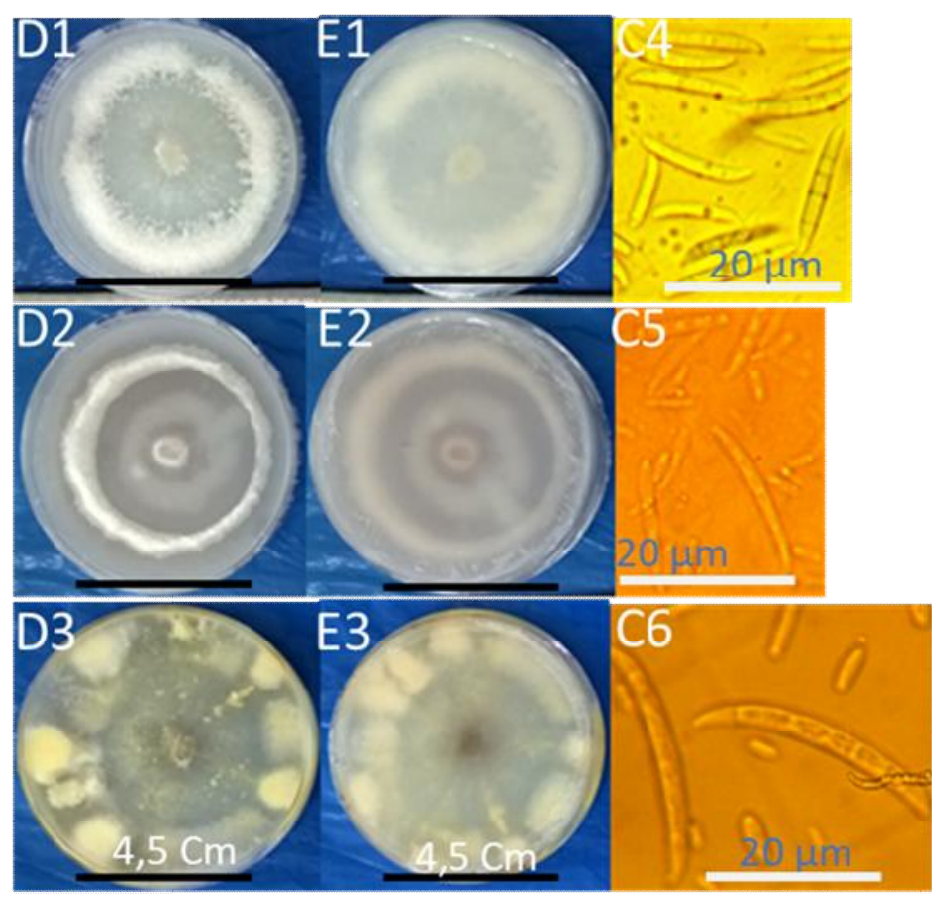

Fig. 3. Morpho-cultural and microscopic characteristics of isolates of the genus Fusarium sp. (Morphotype SahYSt3: D1 and E1: cottony phenotype with $15.2 \mathrm{~mm} /$ day (growth); C4: conidia size $55.4 \times 4.4 \mu \mathrm{m}$ ) (Morphotype MbaASt1: D2 and E2: cottony phenotype with $17 \mathrm{~mm} /$ day (growth); C5: conidia size $53.2 \times 7 \mu \mathrm{m}$ ) (Morphotype DaoASt4: D3 and E3: cottony phenotype with $15.1 \mathrm{~mm} /$ day (growth); C6: conidia size $40.9 \times 7.1 \mu \mathrm{m}$ )
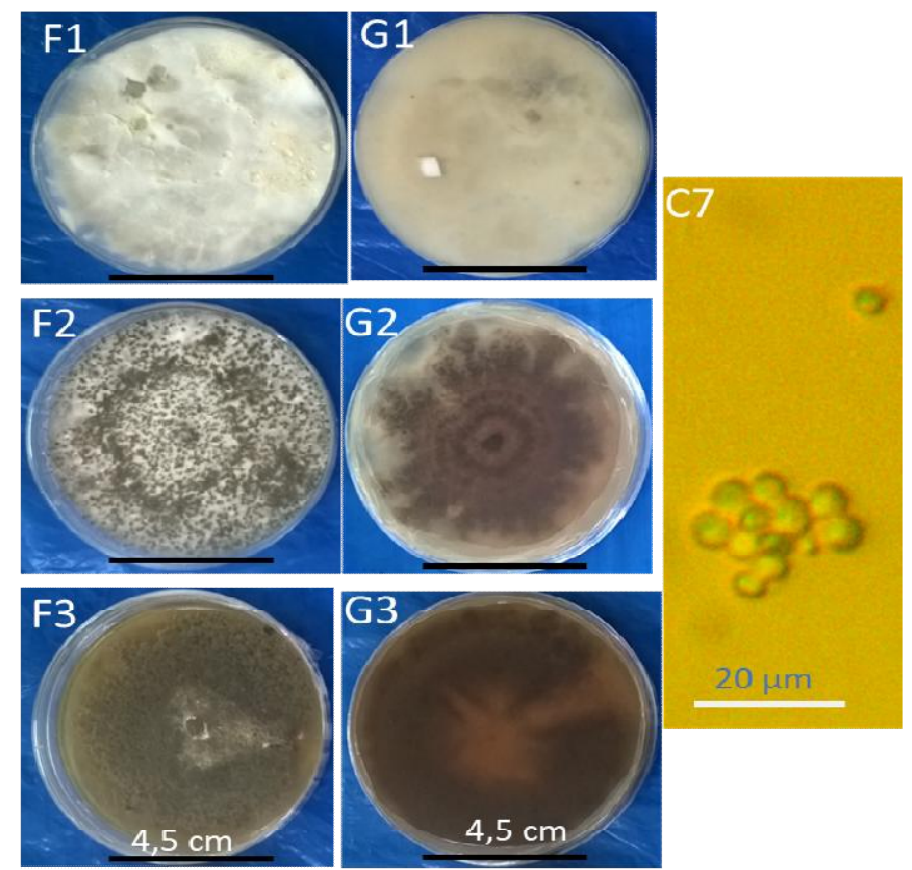

Fig. 4. Morpho-cultural and microscopic characteristics of isolates of the genus Botrytis sp. (Morphotype BiaRSt3: F1 and G1: cottony phenotype with $17 \mathrm{~mm} /$ day (growth); C7: conidia size $6.6 \times 7.9 \mu \mathrm{m}$ ) (Morphotype MakASt4: F2 and G2: cottony phenotype with $17 \mathrm{~mm} /$ day (growth); conidia size $7.4 \times 7 \mu \mathrm{m}$ ) (Morphotype DivASt3: F3 and G3: cottony phenotype with $10.1 \mathrm{~mm} /$ day (growth); conidia size $6.7 \times 6.6 \mu \mathrm{m}$ ) 
Table 2. Parasitic activity of fungal populations of mycoflora associated with cassava anthracnose disease symptoms

\begin{tabular}{|c|c|c|c|}
\hline Fungal populations & $\begin{array}{l}\text { Parasitic pressure of } \\
\text { genera }(\%)\end{array}$ & $\begin{array}{l}\text { Mean diameter of } \\
\text { necrosis }(\mathrm{mm})\end{array}$ & $\begin{array}{l}\text { Mean aggressiveness } \\
\text { index }\end{array}$ \\
\hline Botrytis sp. & $82 b$ & $46 \pm 0,07 b$ & $3 \pm 0,00 \mathrm{~b}$ \\
\hline Fusarium sp. & $100 a$ & $71 \pm 0,24 a$ & $4 \pm 0,75 a$ \\
\hline $\begin{array}{l}\text { Colletotrichum } \\
\text { gloeosporioides }\end{array}$ & $100 a$ & $72 \pm 0,22 a$ & $4 \pm 0,80 a$ \\
\hline Non identifiées & $75 \mathrm{c}$ & ND & ND \\
\hline
\end{tabular}

\section{DISCUSSION}

Cassava anthracnose disease is manifested by a small number of superficial cankers located on added stems. It has been observed deformations due to swelling and distortions of petioles and stems. Also, damaged and necrotic green stems and petioles as well as dried apical buds and dieback were observed. Similar symptomatic observations have also been reported in assessments of cassava anthracnose in Cote d'Ivoire [4], Congo [21,22] and Nigeria [7,11]. Mycoflora, associated with cassava anthracnose symptoms, include fungal morphotypes of genera Colletotrichum gloeosporioides, Fusarium sp., Botrytis sp. and unidentified species. Indeed, this diversity of fungal pathogenic genus, linked to cassava infections, on one side, was revealed by the results of Nyaka [9] after identification of pathogenic fungi associated with cassava root rot in Cameroon. On other side, diversity of fungal genera associated with anthracose symptoms has been observed in Ivory Coast. Silué [10] identified Colletotrichum gloeosporioides, Pestalotia heterocomis, Lasiodiplodia theobromae genera and unidentified fungal strains on symptomatic cashew (Anacardium occidentale L.). The identifications were based on morphological and microscopic characteristics. Our morpho-metric results, both macroscopic and microscopic, are consistent with those of Fokunang [8], Ferrada [23] and Burgess [24] respectively for the genera Colletotrichum gloeosporioides, Botrytis sp. and Fusarium sp.. In addition, the proportion and parasitic fungal pressure were significant for all genera encountered. Colletotrichum gloeosporioides and Fusarium sp. genera were more observed on samples from non-lignified parts and on petioles of plants with lesions and necrosis. Indeed, the genus colletotrichum gloeosporioides has been identified as infectious agent causing cankers, lesions, necrosis and dieback on all the aerial organs of cassava affected by anthracnose in Ivory Coast [4], Congo [22] and Nigeria [19]. Also, Fusarium sp. genus has been identified as infecting 150 plant species in several modes of infection [25], most commonly causing stalkrots. The genus Botrytis has been more encountered on stems deformations and necrosis. This genus would cluster infectious agent from leaves, stems, flowers, fruits and seeds of 500 plant species causing distortions, cankers and rotting. As a necrotroph, it often takes advantage of damage resulting from other pathogens to produce symtoms often call gray mold [26,27]. These three genera Botrytis sp., Fusarium sp. and Colletotrichum sp. occupy respectively the 2 nd, 4th and 8th ranks, in terms of fungal pathogens of economic and scientific importance [28].

\section{CONCLUSION}

Tissues symptomatic of cassava anthracnose disease host a diverse associated mycoflora of which Colletotrichum gloeosporioides species and the genera Fusarium and Botrytis are the most representative fungal population. They are a source of high parasitic pressure through the activity of different morphotypes, encountered at all stages of anthracnose infection. These three genera have economic and scientific importance recognized by the scientific community. Their occurrence in the mycoflora of cassava anthracnose disease symptoms reveals a major phytosanitary problem that opens up multiple fields of study including control approaches, such as the use of bio-pesticides, and molecular analysis of morphotypes.

\section{COMPETING INTERESTS}

Authors have declared that no competing interests exist. 


\section{REFERENCES}

1. Krabi ER, Assamoi AA, Ehon AF, Diawara B, Niamké LS, Philippe T. Production d'attieke (couscous à base de manioc fermente) dans la ville d'abidjan. European Scientific Journal. 2015;11(15):1857-7881.

2. Fao (Food and Agriculture Organization of the United Nations); 2016. FAOSTAT_database.

http://www.fao.org/faostat/en/\#home. Accessed 28/08/2017.

3. Hahn SK, Ikotun $\mathrm{T}$, Theberge RL, Swennen R. Major economic diseases of cassava, Plantain and cooking starchy bananas in Africa. Tropical research. 1989;22:9.

4. Yeo FE, Ehui KJN, Amari Ler-N`Ogn DGE, N'Guetta AS-P, Kone D. Distribution and incidence of cassava anthracnose in Côte D'Ivoire and pathogenic characteristics of Colletotrichum gloeosporioides Penz manihotis isolates. Plant Pathology Journal. 2017;16:73-81

5. Ghini R, Bettiol W, Hamada E. Diseases in tropical and plantation crops as affected by climate changes: current knowledge and perspectives. Plant Pathology. 2011;60(1): 122-132.

6. Tata Hangy KW, Mahungu NM. Les principales maladies du manioc en République Démocratique du Congo et leurs moyens de lutte, In Manuel de formation destiné aux agents de terrain 1, Institut International d'Agriculture Tropicale (IITA) (CGIAR). 201:2:14-23.

7. Obilo OP, Ikotun B, Ihejirika GO, Beawuchi II. Reaction of selected cassava cultivars to cassava anthracnose disease (CAD) in Nigeria. Journal of Animal \& Plant Sciences. 2009;3(2):186-193.

8. Fokunang $\mathrm{CN}$, Dixon $\mathrm{AGO}$, Akem $\mathrm{CN}$, Ikotun T. Cultural, morphological and pathogenic variability in Colletotrichum gloeosporioides Manihotis isolates from Cassava (Manihot esculenta) in Nigeria, Jounal Biology Sciences. 2000;3:542-546.

9. Nyaka NAIC, Kammegne DP, Ntsomboh NG, Mbenoun M, Zok S, Fontem D. Isolation and identification of some pathogenic fungi associated with cassava (Manihot esculenta Crantz) root rot disease in Cameroon. African Journal of Agricultural Research. 2015; 10(50):45384542.

10. Silue N, Soro S, Kone T, Abo K, Kone M, Kone D. Parasitical Fungi in Cashew
(Anacardium occidentale L.) Orchard of Cote d'Ivoire. Plant Pathology Journal. $2017 ;: 16(2): 82-88$.

DO:doi.org/10.3923/ppj.2017.82.88.

11. Wokocha RC, Nneke NE. Cassava anthracnose disease and varietal screening for resistance in Akwa Ibom state of Nigeria. Journal of Agricultural Science and Technology. 2011; 1:889-895.

12. IITA. Cassava in tropical africa. IITA, Ibadan, Nigeria. 1990;109.

13. Fokunang CN, Dixon AGO. Post-harvest evaluation of Colletotrichum gloeosporioides f. sp. manihotis on Cassava Genotype. Plant pathology Journal. 2006;5(1):60-66.

14. Webster J, Weber RWS. Introduction to Fungi; 2007.

Available:www.cambridge.org/9780521807 395. (Accessed 13/12/2017)

15. Barnett HL, Hunter BB. Illustrated genera of imperfect fungi. APS Press, The American Phytopathological Society. St. Paul, Minnesota. USA. 1998;218.

16. Malloch D, (Department of Botany, University of Toronto). Moulds, Isolation, cultivation, identification; 1997.

Available:http://website.nbmmnb.ca/mycologywebpages/Moulds/Mould s.html.

(Accessed 26/11/2018)

17. Sofi TA, Muzafer A, Beig GH, Hassan D, Mushtaq A, Aflaq $\mathrm{H}$, Ahangar FA, Padder BA, Shah MD. Cultural, morphological, pathogenic and molecular characterization of Alternaria mali associated with Alternaria leaf blotch of apple. African Journal of Biotechnology. 2013;12(4): 370381.

18. Spurr, HWJr, Welty RE. Incidence of tobacco leaf mycoflora in relation to brown spot disease and fungicidal treatment. Phytopathology. 1972;62:916-920.

19. Kouame GK, Sorho F, Kone D, Bomisso LE, Ake S, Yatty J. Activité pathologique comparée de deux isolats de Colletotrichum gloeosporioïdes (penz.) sur deux variétés de mangues (Mangifera indica L.). Agronomie Africaine. 2011; 23(1):33-41.

20. Wokocha RC, Nneke NE, Umechuruba Cl. Screening Colletotrichum gloeosporioides $\mathrm{F}$. $\mathrm{sp}$ manihotis isolates for virulence on cassava in Akwa lbom State of Nigeria. Agro-Science Journal of Tropical Agriculture, Food, Environment and Extension. 2010;9(1):56-63. 
21. Makambila C. Etude de l'anthracnose du manioc (Manihot esculenta Crantz) et son agent pathogène Colletotrichum gloeosporioides Penz f. sp. manihotis Henn. Thèse de Doctorat d'Etat. Univ. de Clenuont II. France. 1987;1-154.

22. Boher B, Danielle JF. Anthracnose du manioc en République populaire du Congo. Tropicultura. 1982;1-8. Available:horizon.documentation.ird.fr/exldoc/pleins_textes/.../01389.pdf

23. Ferrada $\bar{E} \bar{E}$, Latorre BA, Zoffoli JP, Castillo A. Identification and characterization of Botrytis Blossom blight of Japanese plums caused by Botrytis cinerea and $B$. prunorum sp. nov. in Chile. The American Phytopathological Society. 2016;106(2): 155-165.

24. Burgess LW, Summerell BA, Bullock $S$, Gott KP, Backhouse D. Laboratory Manual for Fusarium Research, 3rd ed. University of Sydney and Botanic Garden, Sydney, Australia; 1994.

25. Rana A, Sahgal M, Johri BN. Fusarium Oxysporum: Genomics, Diversity and Plant-Host Interaction. In Developments in Fungal Biology and Applied Mycology, édité par Tulasi Satyanarayana, Sunil K. Deshmukh, et B.N. Johri, 15999.
Singapore: Springer Singapore, 2017. DOI:https://doi.org/10.1007/978-981-104768-8_10.

26. Hua L, Chen Y, Zhang Z, Li B, Qin G, Tian S. Pathogenic mechanisms and control strategies of Botrytis Cinerea causing postharvest decay in fruits and vegetables. Food Quality and Safety. 2018;2(3): 111-19. DOI:https://doi.org/10.1093/fqsafe/fyy016.

27. Walker A-S, Gautier A, Confais J, Martinho $D$, Viaud $M$, Le Pêcheur $P$, Dupont J, Fournier E. Botrytis Pseudocinerea, a New Cryptic Species Causing Gray Mold in French Vineyards in Sympatry with Botrytis Cinerea. Phytopathology. 2011;101(12): 1433-45.

DOI :https://doi.org/10.1094/PHYTO-0411-0104

28. Dean R, Jan ALVK, Zacharias AP, Kim EH-K, Antonio DP, Pietro DS, Jason JR. The Top 10 fungal pathogens in molecular plant pathology: Top 10 fungal pathogens. Molecular Plant Pathology. 2012;13(4): 414-30.

DOI:https://doi.org/10.1111/j.13643703.2011.00783.x.

(c) 2018 Nestor et al. This is an Open Access article distributed under the terms of the Creative Commons Attribution License (http://creativecommons.org/licenses/by/4.0), which permits unrestricted use, distribution, and reproduction in any medium, provided the original work is properly cited.

Peer-review history:

The peer review history for this paper can be accessed here: http://www.sdiarticle3.com/review-history/47294 